\title{
Remote English Teaching during Covid-19 Pandemic: Challenges and Lessons in Higher Education Teaching in Colombia
}

\author{
Ensino Remoto de Inglês no Contexto da Pandemia Covid-19: Desafios e Aprendizagem no Ensino
} Superior na Colômbia

Enseñanza Remota de inglés en el Contexto de la Pandemia del Covid-19: Desafíos y Aprendizajes en Enseñanza Superior en Colombia

\begin{abstract}
The objective of this article is to do bibliographic research lined up with the worldwide COVID-19 pandemic in which the main focus will be inclusion, Pygmalion effect as well as teaching and learning remotely. The basis is to gather different perspectives to build knowledge through exhaustive reading of books, doctoral dissertations, masters programs dissertations, current news, reliable sources of information, scientific papers, and own experience amongst others. The analysis of this bibliographic research will be useful for future research on topics related. Emotional and affective relations are important and have impact when facing English learning difficulties and when working to have inclusion. In the context of Covid-19, the learning and teaching conditions got complex when migrating to virtual classes. Remote teaching is not a solution to face learning and teaching difficulties. In this way, affection is the best tool for inclusive learning in virtual environments. It is said that one of the biggest barriers is teacher's formation whose career is based on traditional pedagogy not easily adaptable to digital environments. This situation creates a deep feeling of frustration in teachers, which can be reflected in the low academic performance of English students. Several reflections will be made to encourage the actors involved in the teaching-learning process and in the educational system to ask themselves: Which are the challenges of remote teaching and learning during the Covid-19 pandemic being inclusive through the Pygmalion effect?
\end{abstract}

Keywords: Education; Distance education; Pandemic; Covid-19; Learning; Teaching; Pygmalion effect; Remote teaching; Remote learning; English language; Remote education.

\section{Resumo}

O objetivo deste artigo é realizar uma revisão bibliográfica situada no contexto da pandemia global do Covid-19, onde se busca uma revisão sobre a inclusão, o efeito Pigmaleão, ensino e aprendizagem à distância, cuja base é reunir fontes de conhecimento através de leitura exaustiva de livros, artigos científicos, teses de doutorado e mestrado, notícias reais e fontes confiáveis, dissertações, além de experiência profissional, entre outros. A análise dessa bibliografia garantirá a fundamentação teórica deste artigo e, claro, contribuirá para pesquisas futuras. O estudo considera que as relações afetivas têm impacto e fundamental importância diante das dificuldades para aprender inglês e na direção do alcance de perspectivas inclusivas. Neste contexto de Covid-19, as condições de aprendizagem foram extremamente agravadas pela migração para a virtualidade. O estudo compreende que ensino remoto é um paliativo emergencial e não resolve os problemas de aprendizagem e ensino. Dessa forma, a afetividade é a melhor ferramenta para o ensino inclusivo para aprender em ambientes virtuais. Acredita-se que a barreira mais importante esteja na formação do professor cuja carreira se baseia em pedagogias tradicionais e que não se adaptou facilmente aos ambientes digitais, gerando um alto grau de frustração no professor que se reflete no baixo desempenho acadêmico de professores e alunos de inglês. Espera-se promover diferentes reflexões que levem os atores envolvidos no sistema educacional a se perguntarem quais são os desafios do ensino e aprendizagem remotos de inglês durante a pandemia do Covid-19, sendo inclusivo através do efeito Pigmaleão?

Palavras-chave: Educação; Educação a distância; Pandemia; Covid-19; Aprendendo; Efeito Pigmalião; Ensino remoto; Aprendizado remoto; Ensino; Língua inglesa. 


\section{Resumen}

El objetivo de esta artículo es realizar una revisión bibliográfica enmarcada en el contexto de la pandemia mundial Covid-19 en donde se busca hacer una revisión con respecto a la inclusión, el efecto Pigmalión, la enseñanza y aprendizaje remoto, cuya base es reunir fuentes de conocimiento a través de la lectura exhaustiva de libros, artículos científicos, tesis doctorales y de maestría, noticias reales y de fuentes confiables, disertaciones, además de la propia experiencia profesional, entre otros. El análisis de esta bibliografía garantizará la fundamentación teórica de este articulo y por supuesto contribuirá a futuras investigaciones. Las relaciones afectivas tienen impacto e importancia al momento de enfrentar dificultades de aprendizaje de inglés y lograr que haya inclusión. En este contexto de Covid-19 se agravaron las condiciones de aprendizaje al migrar a la virtualidad. La enseñanza remota no resuelve los problemas de aprendizaje y enseñanza. De esta manera la afectividad es la mejor herramienta para una enseñanza inclusiva para aprender en entornos virtuales. Se cree que la barrera más importante está en la formación del docente cuya trayectoria se basa en pedagogías tradicionales y que no han sido fácilmente adaptables a los entornos digitales creando en el profesor un grado alto de frustración que se ve reflejado en el bajo rendimiento académico de los estudiantes de inglés. Se espera hacer diferentes reflexiones que conlleven a los actores involucrados en el sistema educativo a preguntarse ¿cuáles son los desafíos de la enseñanza y aprendizaje remoto de Inglés durante la pandemia de Covid-19 siendo inclusivos a través del efecto Pigmalión?

Palabras clave: Educación; Educación a distancia; Pandemia; Covid-19; Aprendizaje; Efecto Pigmalión; Enseñanza remota; Aprendizaje remoto; Enseñanza; Inglés; Enseñanza remota; Lengua inglesa.

\section{Introduction}

In times of big changes, people who cannot learn cannot go along with the changes that history brings. Without learning, there is no possibility of adapting to changes in any possible scenario. Human beings learn and adapt. Due to this learning ability, the human race has been able to adapt to evolve. Humankind has learned new ways to live, work, adapt, conquer new spaces, lead and even new ways to interact with others.

Those who cannot adapt especially in the current context created by the pandemic of Covid-19, have had endless disadvantages in their development as human beings. The gap of inequality has increased meaningfully all around the world. Acording to De Oliveira et al. (2021) who quote Putra et al (2020) there are several obstacles related to the implementation of learning activities at home.

According to the authors mentioned above, every person should have the same rights and conditions to be able to face a life-changing process; this means, governments should have public policies to guarantee citizens equal access to transform and adapt to the world without prejudices and damages, independently of their his or her financial condition, for example.

Mentioning again De Oliveira et al. (2021) when citing Carlos Roberto Jamil Cury (2012):

The history of the right to education is similar to the fight for a protectionist labor legislation in new industries. In both cases, it was in the XIX century when the basis for social rights for citizens were accomplished [...] "education is a necessary prerequisite in civil freedom" and a must to be able to access all human rights. The State, in this case, by interfering in the social contract, was not in conflict with civil rights. At the end, intelligent people, with good sense, must use them and therefore, according to the author, reading and writing are indispensable (Cury, 2012).

It is possible to guess that when a good purchasing power he or she has more possibilities to buy better technological devices. Those who have a lower income have less economical possibilities to access to basic rights such as housing, food, high quality education, and also have difficulties to access good technology and connectivity. The lack of access to technology, internet and other information technologies affect a big percentage of the world's population who live in unequal conditions.

In this same sense, the authors mention the Universal Declaration of Human Rights in which it is established that all are equal so that every person has the same rights and the same duties. The Universal Declaration of Human rights is one of the prettiest documents ever written because it includes every single right a person needs and that are infringed by the society as a whole. Reality tells that there is a huge gap among equality and inequality. Inequality is the common denominator in global society. Inequality seems to be a living organism that as a living creature rows and it seems like it has an endless growth. 
Society watches with its own eyes how justice makes inequality legal for society. Inequality is disloyal but society makes not enough effort to close the gap, and this makes it sadly real.

Then, it is not possible to talk about equality, freedom, sorority, empathy, justice, education and other rights taking into consideration the wide gap in basic rights in Colombian society such as housing, education, health, security, protection for those who are more vulnerable and children's protection, amongst others. It seems that the Colombian population who is more vulnerable and less favored with worst social and economic conditions are the last thing in the governments' agendas. There are programs which in theory, should be for those who are the most vulnerable, but the percentage of accomplishment of these programs is low.

Talking specifically about Colombian education, in the context brought by the COVID-19 pandemic, in 2021, 70 thousand million Colombian pesos got magically lost from the Ministry of Communications and Technology that were supposed to be used to guarantee internet access both in hardware and infrastructure to 14.000 schools in the national territory. That amount of money would have guaranteed that for 2022, $70 \%$ of Colombians would have had connectivity with the entire world, and it was especially allocated to the departments that have more educational and economic inequality, such as Amazonas, Arauca, Cundinamarca, Bolívar, Boyacá, Casanare, Cauca, Chocó, Magdalena, Nariño, Putumayo; Quindío, Risaralda, Valle del Cauca y Vichada. These 14.000 schools do not have and will not have the infrastructure nor the hardware to allow children of rural areas to continue with their learning process during the COVID-19 pandemic.

Image 1. Digital Center in the department of Bolívar. One of the beneficiaries of the 70 thousand million Colombian pesos investment that disappeared. Source: https://www.infobae.com/america/colombia/2021/08/30/duque-asegura-que-los-70-milmillones-del-contrato-del-mintic-estan-protegidos/

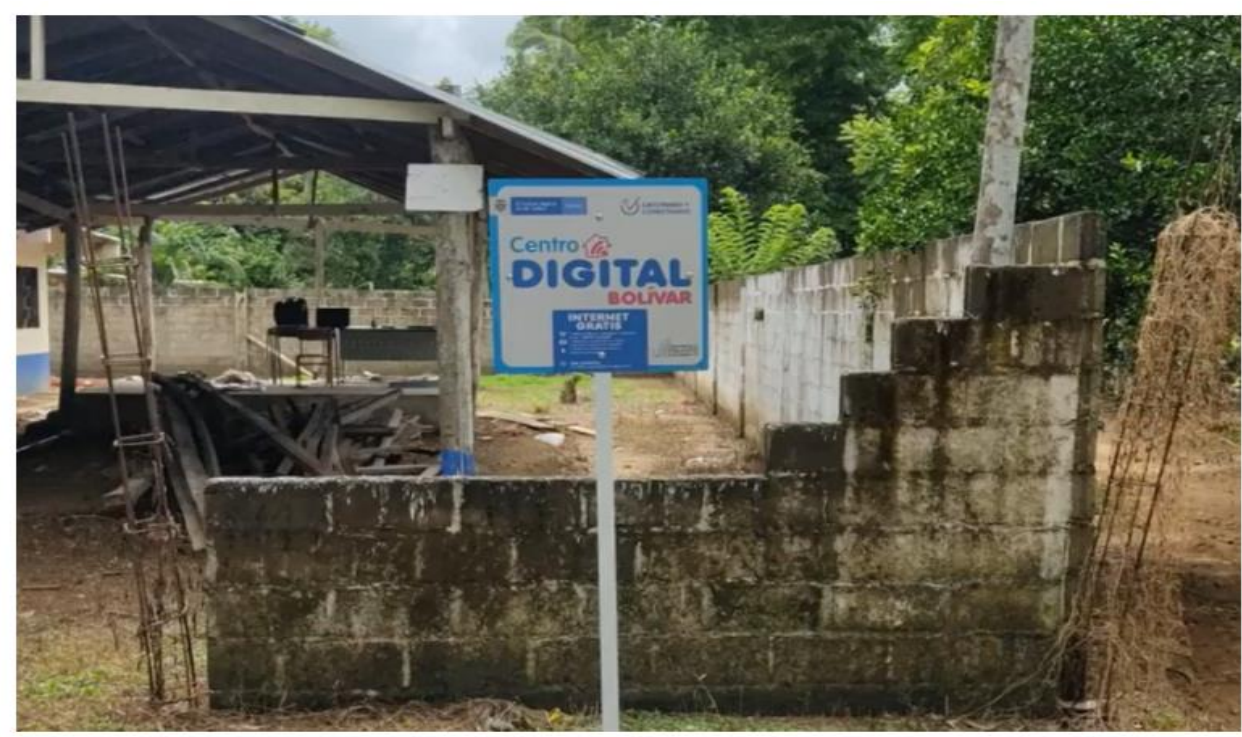

Centro Digital de Bolivar que exhibió la Unión Temporal Centros Poblados y aseguró que ya había instalado 845 hasta el pasado 31 de julio

Source: Authors.

About the socioemotional aspect, it was possible to be more inclusive even when students were facing difficulties due to the COVID-19 pandemic. Teachers were more aware of being empathetic with each and all of their students; giving them calm and taking into consideration their own personal and family situation, valuing them and at the same time they accompanied and persisted in encouraging students to comply with their academic responsibilities. It was possible to evidence that teacher's expectations are a key factor for the success or failure associated to emotional aspects of students. This means 
that the emotional state of students have an impact on academic performance. If the student does not believe in him/herself there is no possible positive accomplishment of the academic and formative process (Miraz, 2014). The possibilities of inclusion and exclusion in the academic environment are also growing as it is mentioned in the book "¿Qué será mañana?" (Pereira, 2020).

\section{Methodology}

This article is based on narrative bibliographic research about inclusion, Pygmalion effect, remote teaching during the COVID-19 pandemic, which base is to compile and reveal knowledge from books, articles, thesis, news, dissertations, and personal experiences amongst others. The analysis of this bibliography is the theoretical foundation of this article, which will contribute to future research. This narrative bibliographic research has no specific research criteria, has an arbitrary selection of articles, the analysis includes a personal point of view of the researchers, and the scientific evidence is made to be questioned.

The narrative bibliographic research has as an objective to describe and or discuss the current state of a specific topic. It does not need to have a detailed description of the sources used or the methodology to look for the information. The researchers select the articles based on their theoretical point of view of the topic being studied.

This article will have as a ground base the following:

2.1 According to the authors de Oliveira et al. (2021), Brazil was not particularly prepared to advance in education during the pandemic. There was lack of preparation in infrastructure, with high social inequality and distancing of their population about new technologies. This was hard work for teachers and educational staff. The pandemic caused even more digital exclusion added to the one that already existed. The pandemic also revolutionized the way of having direct contact amongst different generations with technology, and the way this relation will impact the forthcoming generations is still a big question. Pereira (2020) is conclusive when highlighting that the context created by the COVID-19 pandemic is the perfect time to show the importance of socio-environmental education to increase humans longevity on Earth and the way a life full of hope is waiting for the human race.

This article brings a qualitative discussion about the way that new knowledge interferes in the difficult reality of millions of families that could be part of the remote educational system but due to their economic reality, which in theory should not affect their right to education, have been affected and excluded.

The observations, reflections, and conclusions made here are based on daily facts and situations that come from own experiences that the observer had as being included in the research as a teacher and professor, living the same difficulties as most of the observed population. It was imperative to focus on the general observation of facts avoiding the description of specific and particular situations yet creating knowledge about a generalized condition cause by the lack of new technologies that promote new ways of teaching and learning.

2.2 As de Oliveira et al. (2021) mention by quoting Ludke and André (1986) "to be a valid and reliable tool for scientific research, the observation must be controlled and systematic".

Knowledge is a conscious and an intentional act to learn from the qualities of the object. It is first referred to the subject, He/She who knows, but at the same time is the thing that is its object, the What is being known. Its development has grown as the human knowledge has evolved. Epistemology studies knowledge and both are basic elements in scientific research, which begins with a hypothesis, which is treated with mathematical models to be proved which finishes with valid and reproducible conclusions. Scientific research is an accepted and validated process to solve questions or new facts led to know principles and laws that support humans and their world; it has its own system based on the method of 
hypothesis/deduction/induction complemented with statistical calculations and probabilities. Being able to manage in a good way theoretical knowledge in scientific research allows answers to be correct and technical to any hypothesis. This is why the scientific researcher should know his/her theory and its evolution (Ramírez, 2009).

This article has as its first source scientific research through internet. As de Oliveira et al. (2021) say, "Everything that can be discovered is available nowadays in worldwide computer network. In this way access and accessibility to information is worked, considering not only the benefits but also the difficulties faced by the population in a hostile context. They have neither connectivity nor access to new information and communication technologies. It was very difficult to do such deep research without a process of divulgation of the information compiled, the papers, research and articles on the internet".

Despite Covid-19 is a new topic, it has created an enormous revolution in the world. This revolution has made all humanity feel uncomfortable and has changed the way the humankind was living, and it has created a new way of living. Education as it used to be, changed in a minute and the traditional model of face-to-face classes was forced to change to remote teaching and learning. The pandemic has been a breaking point for humanity and inclusion plays an important role to be able to adapt to a new way of living.

\section{Results and Discussion}

Inclusion and exclusion are a trend in the educational system, as mentioned in the book "¿Qué será mañana?" (Pereira, 2020).

"Often, very close to us, pain and human suffering are present as a joke and we have difficulties to notice them. COVID-19 has brought us back home, it has given us the need to take care better of the people that are close to us, to be in touch with oneself, to make sure we recognize which things are worth and to recognize how much we need each other. This need is so important that we had to isolate ourselves to recognize its value. The other is part of me. Living with others (the ones who are closer) has now a great meaning in my existence. Surviving depends on taking care of the other... "I take care of others, then, I exist". In this perspective, we learn to tolerate the singularity of others".

Having this in consideration, worrying about students by the teacher implies not only to recognize that without them there is no teaching, but it also implies emotional inclusion from the affective perspective and the different learning necessities. There are researches (Castillo, 2014; Boser et al., 2014; García, 2013) that assert that the Pygmalion effect is an effective tool for the students to develop thoroughly through external stimulation. This, with the objective of self-development, and at certain point, being their own internal motivation to learn, turning themselves into their own Pygmalion, which implies that he or she includes him/herself in the educational system.

Likewise, it has been proven that there are teachers who have the lowest expectations about their students, and they sometimes predict who goes into a University and who graduates. There are, as well, teachers who have the lowest expectations about their students, who need high expectations and support (Boser et al. 2014). It has been found that some teachers believe that students of a specific race or social strata close to poverty have fewer probabilities to graduate from higher education. Social stereotypes have also been a key factor for teachers who build opinions about their students and their future performance. The Pygmalion Effect is connected both to inclusion and education, and therefore it is necessary that not only teachers, but everyone involved in the macro and micro policy decision-making of the educational system raise their expectations about students and promote educational inclusion, starting by the class micro-environment.

Recognizing the other, in this case both students and teachers is fundamental. "The otherness, the acceptance and care are the base of the new ways of being in which the meaning of life is what guides that "being" in times of COVID-19. Bonding amongst humans to transcend the way people relate through social network connections provides a solidarity sense with thousands of human beings that have their daily life more threatened than us, due to their conditions and non-available 
resources" (Pereira, 2020). By recognizing that the students of a particular group and their teacher are vulnerable beings with different capabilities, and promoting solidarity, empathy and tolerance might create a learning environment that, despite the fact of being strongly affected by the pandemic, can have a learning and teaching environment suitable for both. Teachers must be more critical, analytical, and sensitive to be able to identify the factors that can promote that process of recognition of the other in the classroom. In addition, that makes them aware of the need of being solidary, empathetic, and tolerant. At the same time, it guarantees both teacher and students the best results in academic performance. This will guide the learning and teaching process in acquiring more knowledge and being inclusive in the process of teaching-learning and in their future professional lives.

Given the situation that the educational field and the world is facing due to the SARSV-Covid-19 pandemic everything has been reformulated. The educational field, adapted by using emergency virtual education and several months after they turned to remote teaching. None of the following factors were taken into consideration: teacher's preparation to face technological resources, on-line teaching planning, students' preparation for this environment, anxiety, efficiency in learning and teaching, and more importantly, students' motivation (Gusso et al. 2020). This is evidence that during the migration from face-to-face classes to remote classes, the Pygmalion Effect and inclusion are even more relevant. This article focuses in the positive and negative effects that the teacher has in students' learning process.

It is necessary to revise the different ways in which the exercise of teaching can improve to make the learning effective in a classroom, accomplishing the inclusion of all students taking into consideration their different characteristics and conditions (economical, race, social, among others). All this, having the human being in the center. This research is also based on how determining the expectations of a teacher about their students are keeping into account the different types of human intelligence, learning styles, inclusive education and emotions as key factors for the self-concept, self-esteem and for the academic performance, in this case in the English class. The class environment is that ecosystem where teaching and learning, socialization, bonding between teacher and students, amongst students, bonding between mind, spirit and knowledge take place. That ecosystem is guided by the teacher, who plays a fundamental role in the formation and determination of the life of his/her students, both in the academic dimension and all the others that are part of the educational processes.

In the experience that has been lived as a student and teacher, the researcher has seen the importance of thoughts, feelings, and attitudes, that consciously or not the teacher and his/her influence along the life of human beings, determine in great sense, from the expectations that teachers have about each person in their classroom. In the context of remote learning due to the pandemic, both students and teachers have different expectations and a rejection barrier towards the teaching methodology and learning process guided by remote teaching and learning. It is possible then, that in the learning and teaching process during the pandemic not only the expectations of both teachers and students are determining, but also the motivation or rejection towards the remote learning and teaching might be less favorable.

This research can offer results to face the negative factors related to exclusion in the class ecosystem, English remote learning, and the pandemic to improve the conditions that would lead to a better academic performance of students. This research will provide the scientific community a detailed bibliographic revision about improving students' academic performance by being inclusive through the Pygmalion effect in times of pandemic, which has not been studied yet.

For the Higher Education institutions, student's academic performance is key when the quality of education in a university is measured. Academic performance is composed by the accomplishments of each student in academic tasks, so he/she can advance in their curricular itinerary. It is measured through the quantitative grades a student gets. For some, the grades a student gets are a key performance indicator in which, along with the academic accomplishments, there are different gaining in learning and other benefits in their personal and social dimensions. Each university establishes which factors will be considered to measure the academic performance of its students. As it was said before, the academic performance can be 
determined or affected by the personal life of a student, the teacher, the personal context, and the institution. The question is then, which are de challenges of English remote teaching and learning during the COVID-19 pandemic being inclusive through the Pygmalion Effect?

In the languages learning process both the self-esteem and the self-concept are affected by anxiety, frustration, fear, for example, by making errors at the moment of answering to an activity or situation, both in public and in private. That fear can become stronger when repeating the experience which affects the academic performance by inhibiting the participation in the process. It is amazingly important, that in the class ecosystem, the teacher be aware about the importance of several aspects and that he/she can handle in a positive way moments of anger, stress, depression, sadness, frustration, etc., which are part of every human being and are also part of the process of learning and teaching. Recognizing the efforts of students, their good work, participation, interventions, etc., is fundamental for the accomplishment of good academic performance. When this bibliographic research was started there was a terrifying worldwide context. From one day to another, everything changed. Humans have then, adapted to unexpected situations. In general, the entire world has had to adapt due to the COVID-19 pandemic. In this context, there is an important question for every aspect of human life including education and which is extremely difficult to answer: what does the future hold? In his book “¿Cómo será el mañana?” Pereira (2020) says that "to be able to guarantee life facing COVID-19 it is necessary to have collective actions and support of everyone in the world". A classroom is a privileged place to offer support and promote taking care of one another. Therefore, the Pygmalion Effect is especially significant when facing different types of difficulties of different sources and types. It is the case of time management, for example, because nobody was prepared to study and teach remotely in his or her family nucleus.

In remote education, in which studying, and teaching takes place in the household, life of both teachers and students are exposed through a screen. In many cases, that exposure is a reason to feel ashamed and vulnerable due to socio-economic reasons or family situations. To be able to have a good performance in a context where every family member has to work and study simultaneously has been an enormous challenge that has not been possible to overcome by many people. It has also been a factor of exclusion, the difficulties faced to access technology, which can become an impediment to for remote education hence impeding learning and teaching activities. The amount of time spent in front of a computer, difficulties to sleep, anxiety, changes of schedules, activities and eating habits, studying methods and routines, bonding with classmates and teachers, have serious consequences in the academic performance of students and the execution of the teaching practice. The real educational processes are ways caring that always make people more human. Dependency on screens, internet and connectivity has affected the bonding amongst classmates and with teachers.

Pereira (2020) asserts that "life is more important than economy": this should be people's logic and reality. Nevertheless, during the pandemic it has been evident that the governments around the world have had big difficulties due to the mandatory lockdowns, and consequently, many industries have closed. This closure of industries have had a huge impact in the life of humanity, survival, inclusion and exclusion of lots of people around the world. People have lost their jobs, businesses have broken, they have less or no incomes, and this is reflected in a worse quality of life. Other consequences have been the lack of health; some have had to choose between providing food to their families or the education of their sons and daughters. This has increased school dropouts in huge proportions. People's health is in crisis and probably economists did not include this in their models to calculate de impact of the pandemic in the world. The world's economy is also in crisis and, therefore the life of many people. In this context, even when "life is more important than economy" there are big difficulties to keep this principle.

Another reality that Pereira (2020) states and that is part of humanity now, including teachers and students, is the difficulty to accept pain and suffering. Very close to each person, human pain, and suffering increases. Covid-19 has implied spending a lot of time at home where the need of taking care of others has been very important, being in touch with oneself, 
recognizing what is worth and how much people need each other. This necessity is so important that it was necessary to be isolated to recognize it. The other one is part of oneself; living with others, with the ones who are closer to us, acquires a huge meaning in existence. Surviving depends on taking care of others... "I coexist, then I exist". In this perspective, it is learned to tolerate the singularity of every being. Covid-19 has brought to light both positive and negative aspects of each human being.

Throughout history, the human has faced a duality between being selfish and sharing, and Covid-19 has been a scenario in which this duality has been more noticeable. It is important to highlight that in pandemic time humans have learned to be solidary and empathetic with others. The pandemic has allowed humans to help others with food to families in unbelievable situations and for families who have lost their jobs. Some people have used platforms as the ones for crowdfunding to collect money to help different communities. This means that even when some people are selfish, values as solidarity and empathy have gained a strong place amongst people. Another example in Colombia is that many higher education institutions have lent all the computers they had to student's teacher and employees, and some have even paid for internet service so that their students are able to take their classes. In the academic context, in the emergency virtual and remote classes both students and teachers have become more tolerant, empathetic and with a high sense of solidarity among them. This is an example of Pygmalion effect.

In this same pandemic context, Pereira (2020) emphasizes that teaching should include respect. This means that is possible to tolerate other people because there is respect. This assertion of the author is essential not only in relation to the Pygmalion Effect but, in this moment with the pandemic and with the process of teaching and learning remotely even more. Putting values into practice such as respect and tolerance in a classroom are key and significant. As mentioned before, remote education implies special conditions: in a virtual classroom where the intimacy of both teachers and students is part of the class (classes are given and received from each participant's house) respect is necessary. Tolerance allows that, for example, none of the participants takes as a personal matter the external stimuli that occur during class and those participants are able to isolate those facts in a conscious way so that they do not interfere with the concentration of the teacher and the students. These could not happen in a class environment where tolerance and respect are not part of it.

Covid-19 has brought important changes: a) taking care of the universe and planet Earth is first than taking care of other things; b) taking care of life in its multiple ways; c) taking care of people; d) taking care of everyone as a collective; e) taking care of spirituality; f) taking care of our surroundings and the environment; g) taking care of health, a systemic caring; h) taking care of the future: changes in ways that humans think and believe are very complex and they take time. With the pandemic a strategy of inclusion and improvement of the academic performance of students in level VIII English class in a private university is a must. These changes not only in the way of thinking of human beings but also in their behavior have accelerated and people in general are slow in reacting to them. Humans should be more aware of the meaning of the verb "taking care of" and how to do it in the best possible way. In the class ecosystem, the teacher is the key in taking care of students and their learning process.

And after Covid-19? It is said that 10 big changes will come in different aspects of life. According to Melo Clayton who is quoted by Pereira (2020) these changes are: a) Deep revision of values; b) less is more; c) rebuilding commercial spaces; d) new business models for restaurants; e) cultural immersion experiences; f) remote work; g) living closely to the working place; h) shop streaming; i) seeking for new knowledge; j) remote and distance learning; amongst others. From the previous list the ones which are more relevant for this research are remote work and remote education, as well as seeking for new knowledge.

Virtual and/or distance education is what students and teachers are facing nowadays (in brief a detailed explanation on the differences between face-to-face education and distance education will be given). They must face it without being able to decide if that modality was what they wanted or not and more especially, without knowing in detail the methodology of 
remote teaching and learning. It has been by far one of the key factors, not considering the economical factor, that has an influenced over high education dropouts during the pandemic because students and teachers feel that they do not learn nor teach in the same way they used to and with the same quality than in face-to-face classes. Remote education, from now on $\mathrm{RE} / \mathrm{VE}$, is a methodology that even though it is not new, will be a great methodology in the post pandemic times.

Searching for new knowledge will continue being necessary because industries around the world need employees and an environment adapted to changes that happen suddenly and need new skills and perspectives that can only be obtained by having new and adapted knowledge. The world's organizations need new skills and abilities for the life and the world postCOVID-19. These new needs and demands create among employees and students the need to learn the best way to cope with a new reality: uses of technology, time management, work/study under pressure, new skills to build social relationships, among other skills.

The post pandemic world has implied the need to adapt as fast as possible (there is no time gap to overthink about changes) without the possibility to decide if the changes are made or not. According to Appenzeller et al. (2020) the use of new pedagogical strategies has brought challenges such as teacher training, students' and teachers' adaptation, mental health of the community, time management to study, work and for other activities, and education access (guaranteed access in the Colombian context) for students. These has turned in a non-stoppable point of discussion among the academic communities around the world. The authors established a series of "steps" that they put into practice to face these concerns. The first step was, to identify students' needs in relation to remote emergency learning support. Then they evaluated the process of learning/teaching in the first week of classes, in the fifth week of classes, and finally in the last month of class. The result of the procedure showed that both students and teachers faced an unstable internet connection and or difficulty to access mobile networks. It also showed that students in the first semesters had more adaptation difficulties to remote learning. Finally, between $10 \%$ and $48 \%$ of students had to share their hardware with other family members. In the first month there was a huge difficulty with synchronous classes, however students said asynchronous activities were easier because they had more time to complete them due to streaming.

Conclusions made by the authors in this study show that it is necessary to: a) guarantee equity in the access to education as a key factor to allow the continuity of the learning and teaching process; b) create strategies as fast as possible to identify the changes in the needs of both students and teachers to be able to provide fast solutions, especially the ones regarding equity; c) listen to students talking about the difficulties that they are facing in their remote learning process is essential; d) create WhatsApp groups, telegram, signal or similar and use their emails to motivate constant communication among students and with the teacher: e) highlight that the stars of the show are students; f) teachers must be aware all the time about students who do not go to class and contact them; g) guarantee for teachers, students and academic staff computers or technological devices and internet connectivity.

It is possible to conclude from this research that in general several items are needed for a quality remote education that is, at the same time, quality learning and teaching processes. Therefore, it is important to train teachers on topics such as: how to record a class, how to include technology in their lesson plans, how to present students with information and knowledge that is easy for them to digest, how to plan their classes in a Covid-19 environment, how to upload material for students to study in different online platforms, amongst others. There must be constant support for teachers. The person responsible for a didactic material needs to keep a record of the didactic material that has been uploaded. This includes where it was uploaded, how it is supposed to be used, its objectives, making immediate adjustments that are needed to make sure that the didactic material includes is good quality but also it is aligned with the pedagogical content that students need to learn.

In this process, there might be difficulties such as didactic material excess and disorganization. To avoid difficulties like these ones and others it is necessary to motivate teachers to be careful with the content of their didactic material, to the 
class objectives clear, to design asynchronous activities, to have essential content as well as supplementary material. This must be a process carefully supervised. Feedback should be given constantly to students and their anxiety should be monitored. Teachers must look for the ways to lower anxiety through a constant activity of listening to students carefully and attentively.

One of the most visible difficulties using remote learning is keeping the privacy of everyone involved in the class. This is because classes are streamed using different technological platforms. Santos (2020) states:

Platforms are being used in the most irresponsible way. Platforms keep users' data and these threatens everything that has been created in an online environment. This is a tragedy in the long term because platforms have been owing the formation of Brazilian culture and identity.

This is one of the reasons why training teachers in recording techniques and use of platforms to upload content should be a must, should be permanent and teachers should have supported all the time. In this way, the risks of uploading information to the internet can be reduced. In the same sense, training should also be for students because they need to learn that a classroom with the methodology of remote learning needs to keep its privacy and intimacy and every member of the class (teachers and students) should protect it and respect it. This could turn out into a great benefit by keeping the cultural identity and intimacy of the class protected.

Higher Education Institutions (from now on HEI) have faced several challenges during the Covid-19 pandemic. Gusso, et al (2020) have identified some of these limitations. In first place, they mention that some skills and abilities cannot be developed under non-presencial methodologies. Some of these skills are, amongst others, social skills, which imply having assertive communication and empathy towards other beings. The authors also mention that education is not "training students to reproduce knowledge" but to train students to face the existing reality from the standing point of the knowledge they have acquired. The authors agree that HEI have taken simple decisions based on three premises that ended up being more a desire rather than reflecting reality in general:

1. Everyone involved in the teaching/learning process has easy access to technological resources.

2. Both students and teachers are in conditions (psychological, physical, and know how to use technological resources) to perform remote activities.

3. Teaching is transmitting content, and if the teacher presents information, the teacher taught, and therefore, students learn.

There was no time to include teacher training for them to face the use of technological resources, lesson plans for remote teaching, amongst others. There was no time to think about students' preparation to be able to cope with this technological methodology and the responsibility and importance of time management. There was no concern at all in taking into consideration key factors such as anxiety, perception of inefficiency of teaching and learning remotely, students and teachers' low motivation, etc. All these difficulties and others have brought to HEIs a challenge to change the perception of everyone involved in the learning and teaching process that believe that teaching is limited to the transmission of theoretical knowledge. This belief does not allow students to create real social transformations. Therefore, learning should empower future professionals to develop attitudes to transform the current and future reality in a correct and effective way and with long lasting. This should be done with systematic efficiency, ethics, affection, empathy, inclusion, technique, scientific knowledge, well-designed policies, always including everyone in society. HEIs should form students able to characterize and face reality and the necessities that society has, in such a way that they learn to learn, and most importantly, able to face a society that is living the reality of a worldwide pandemic and an imminent social transformation. 
Now, talking about the difference between face-to-face education and remote education it is possible to say that faceto-face education has been practiced during centuries and it is basically a model in which teaching happens in a specific physical space: the school, university, institute, etc. In this model, the role of the teacher in the process of teaching-learning is traditionally the most important role of the learning process. Students gather around the teacher to listen to his/her lessons and instructions, which will determine the personal effort each student will do to learn. This is the traditional model, the one of face-to-face teaching and learning. To differentiate face-to-face teaching and learning from remote education, the latter is a model that allows students to continue working on a specific academic content without the need of frequent face-to-face relation with the teacher in a specific physical space, in which, in the traditional model, the teacher will provide knowledge to a group of students. (Universidad del Quindío, 2006, p.4)

One of the differences between face-to-face education and remote education is that the latter focuses on the independence of students, their discipline and time management. It surpasses boundaries and frontiers because more students around the world can access the educational system from places that in pre-pandemic time were not even considered. It offers the possibility of closing the gap between people who cannot access to education and the ones who can. Remote education allows a learning process that is not limited by time, space, occupations, age of student, etc., by means of technological resources. Students are then the stars of their learning process. Remote education implies that the teacher is not an element used to control the classroom, but a guide who through planning and constant feedback by using communication resources, allows the bonding process between teacher and students, amongst students, and between students and the teacher.

Ibáñez, (2020) asserts that there is a big difference between online teaching, virtual teaching, remote emergency teaching and distance teaching:

Online Education: teachers and students interact in a digital environment with technological resources, internet, computers, and mobile devices in a synchronous way (the schedules of the student and the teacher must coincide so they can have the class). In this space, the teacher can create strategies that promote social interaction, group bonding, and a class environment that is safe and comfortable for students and the teacher. For example, online classes are the ones that are given by using platforms such as zoom and have a support platform to upload didactic and complementary material. As an example, in the University where the research is taking place, classes are given by using zoom and teachers are using other tools such as: Edmodo, Blackboard, Google hangouts, Schoology, among others. The platform that this University uses as its main one is Intu/Moodle.

The teacher becomes a tutor because his/her work is to accompany and assist students in their learning process. This methodology has several advantages: a) it has a greater access to information (in relation to time) and this reduces the geographical barriers because people from different places around the world can connect to the class (inequity regarding technological and internet access cannot be forgotten); b) allows students to manage their study time and the allocation given to "study" during their day, which makes their learning process more flexible; c) allows students to be autonomous; d) teachers can accompany students in a better way by having an individual and a group guided processes; e) it motivates spaces to dialogue.

Virtual Education: like online education, it implies the use of technological resources (computer, mobile devices, internet), a platform, but instead of having synchronous activities it emphasizes in asynchronous activities. This means, that the schedule of the teacher and the schedule of the student do not necessarily have to coincide. It is like remote education, but virtual education implies the use of technological resources. The class material is uploaded to a platform and students revise it depending on their time availability. Class discussions and group work can be done using forums, generally. According to all these, the teacher is responsible for uploading the material and giving feedback on time to students. This methodology has 
advantages as well: a) students are autonomous due to asynchronous activities; b) feedback allows students to advance faster and each student can go at his/her own pace.

Distance Education: it can combine face-to-face methodology with virtuality. Students have a better use of time and have a better control and understanding of their learning process. There is no need to have internet connection because other tools are used; among them: notebooks, pen drives, cds, physical material, photocopies, books, open TV, radio, and traditional mail system. This methodology also has advantages: a) it allows time management so a student can administer time not only for academic purposes but also for personal matters; b) it can reach more people taking into consideration all socio-economic levels or where there is no internet access, or mobility is difficult.

Remote emergency education: it is a very useful educational methodology in contingency situations such as the Covid-19 pandemic when all the educational system was in an unthinkable situation in which everything had to be adapted from one day to the next one. Both the curriculum and methodology from face-to-face methodology changed to "virtual" classes, which had to continue to overcome the difficult situation created by the pandemic that was threatening everyone's life. Its main objective is to teach the classes that were designed in a face-to-face methodology to be taught remotely by using online education. Each country assumed this situation in a different way: some countries had a blended methodology: both face-to-face and online education, others had everything online, others cancelled all their classes. In this methodology the most important thing to take into consideration is students' welfare.

With the situation of Covid-19 pandemic that the world is facing, teaching methodologies have changed according to the instructions given by each government and by each institution. For this research, the first semester of 2021 the University had decided to have again face-to-face teaching and learning methodology (for those students who wanted it), hybrid methodology (for the use of labs and experiential classes) and online methodology for all the other courses that did not require a face-to-face methodology. However, with uncertainty in February, the Colombian Government decided that the teaching and learning methodology that the whole country was going to use was online and just laboratories and experiential classes would have free access to the campuses. The reason of this decision was to take care of students' integrity and avoid deciding for to face-to-face classes and then having a new lock down again, as it happened in the first semester of 2020.

\section{English Teaching in Colombia}

The Colombian Government has in its development plan a National Bilingual Plan that started officially in 1997 led by the Ministry of National Education. This program has allowed the allocation of public resources to be used in the training of English teachers. It has brought as a benefit that training teachers in the process of teaching English as a foreign language is fundamental. According to Restrepo, M.B. (2017) foreign languages should be included in the curriculum as part of a strategy that integrate, impact, and strengthen the HEI processes and their students. In research mentioned by the author, it is shown the students' low academic performance in English classes is because their teachers still use traditional methodologies focused on the teacher and do not consider the low interactions that students had. It was also observed that communicative strategies were not clear enough: the activity of translating and grammar center classes were a trend among the classes observed in the research. Teachers are afraid of including innovative activities because they also have low English communicative skills. This means that teachers tend to focus their classes on grammar rather than on pronunciation if they feel their pronunciation is not correct. With globalization, English is a must. English should be the tool to open frontiers, crash social, geographical, and cultural barriers allowing both teachers and students to be more competent. English allows the interaction with the worldwide society, and this should be a topic for teachers to reflect about their praxis because English cannot longer be a technical element but an instrument to potentialize professionals so they can interact with the world in business, culture, and society. About this topic, Cárdenas (2018) shows the evolution of the historical framework to make Colombia bilingual: 
Figure 1: Evolution of Bilingualism in Colombia.

\section{Evolution of Bilingualism in Colombia}

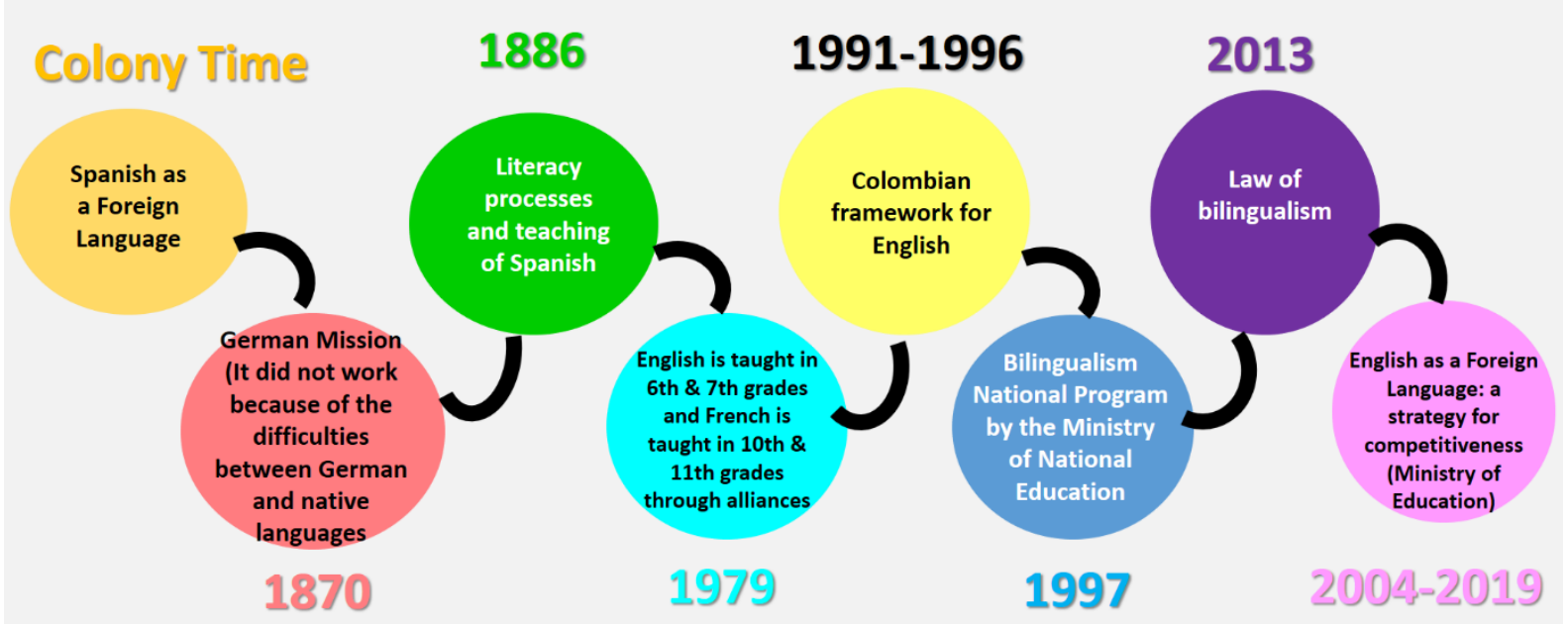

Source: According to Cárdenas, (2018)

As it can be seen, the Governments effort in the last decades have been consistent and public policies have been created for universities to teach English as a foreign language.

For Higher Education Institutions a project to strengthen English was created. This project focuses on Bachelor of Arts, English in this case, which had 3 stages: the first was led by academic peers who made a diagnose of the academic programs; the second stage was to present strategies to improve and to strengthen the programs; and the last one, was a complete guidance by the Ministry of National Education to HEI to implement these strategies. In this process it was evidenced that an inclusion policy is needed because there is exclusion due to economic, social, cultural, and psychological differences as well as because of access to technology differences, cultural identity and because all these exclusion issues there must be a change in the curriculum design in all the programs. For Chávez-Zambano et al. (2017), English as a foreign language is no longer a privilege but a need in every area of life due to globalization. Nowadays, English is considered the Lingua Franca (ELF): the language of the current world.

Cocoma and Orjuela (2017), emphasize on the challenges that the Colombian educational system must face by using the policies about the use of ICTs organized by the Ministry of Technology and Communications (MINTIC). It establishes ICTs as a strategy that allows the development, innovation, and competitiveness through the Project "Live Digital" which main objective was to accomplish by 2019 that all Colombians had to be fully connected, informed, and using communication technologies in an efficient and productive way. In this same document, the Ministry of National Education had as an important goal the National Bilingual Project: it said that by 2018, 35\% of the students in Colombia would go from A2 to B1 level of English according to the Common European Framework. This goal would allow students to communicate better and access to better job opportunities. Unfortunately, with the pandemic, a strong deficiency in the access to internet for students in schools and universities and even teachers were revealed.

\section{Conclusions, Reflections and Challenges}

The teaching and learning proccesess are never ending. Both teachers and students need opportunities to enrich their knowledge and to improve it, they need opportunities to develop new skills and dexterities. Talking specifically about teachers, professional development allows them to find better ways to teach. It is an evolutive proccess, of self-reflection, of growth that if is kept as permanent it allows teachers to have a better and lasting teaching proccess. This is, as said before, a never ending proccess and in the long term it is necessary for different reasons: it helps to adjust the teaching objectives with the students' 
needs and the reality of life; it allows having curriculum adaptations to face the challenges that everyday life brings to the educational system, and not less important, because there is a conection between the way that a teacher teaches and his/her students success.

The emergency caused by Covid-19 (not only the sanitary emergency but also considering every aspect of life) is still alive, and every part of society along the world has had to adapt and face the challenges that this emergency has brought with it. The Educational system has been severely affected. The role of technology has had to be thought again and redesigned for educational processes. The educational processes can be developed with high standards. According to the Ministry of National Education the following aspects should be considered: support for the teachers, active, autonomous, authentic, and relevant learning as well as physical and mental health and interaction amongst students. Therefore, it is important to start putting into practice the policies that the Ministry of National Education established in a document called CONPES 38888 of 2020. It refers to the modernization of telecommunications, information technology access to all Colombians in all the national territory, support to public education through improving connectivity, training in the use of technologies, subsidies for vulnerable families, among others. Not to left on a side, it is important to mention that 70 thousand million pesos got "magically" lost from the Ministry of Technology and Communication, which clearly is an impediment for this goal to be accomplished.

The role of the teacher needs to be focused on the needs of each situation: training in technology, flexible, creative, with empathy, innovative, with a high sense of emotional intelligence and a good socio-emotional management of students. In the same way, it is important to form a group of experts in education mediated by information technology, is needed. They should be responsible for establishing the parameters to have a starting point to train teachers.

The categories that affect students' performance are the support from their teacher, internet connectivity, use of technological devices, possibility to have a technological device, and mental health.

One of the most important challenges is to have teachers feel empathy for their students and to have students feel empathy for their teachers. The same difficulties that teachers are facing, students are facing them as well. The difference is that teachers are the ones who are supposed to have the knowledge. Teachers should be able to manage emotions in a better way during remote classes considering that the interaction is limited, so they need to make sure the interaction that is present in class is effective so that the learning process is authentic, relevant and in this way, the classes are not monotonous and full of homework. Classes should be active. With more empathy and a better use of the Pygmalion Effect, the teacher can lower the negative impact that emotionally the pandemic has brought to the mental health of students. It is exactly in this moment when the Pygmalion Effect is a great tool allowing teachers and students to keep a great quality in their learning process.

Nowadays, society is an information society in which endless information is shared in real time thanks to Internet. This should be then a tool for remote education. However, even when an important part of society is connected through Internet, the pandemic made it evident that there is a lack of connectivity and there is unequal access to it globally. Information has been unmaterialized and is now globalized, everyone should be able to access to it anytime and anywhere, if every single human being has the same rights. This means, they have access to information, connectivity, and a device to look for the information. In an ideal scenario, it should be simple to create, process, and transmit information by creating new educational spaces and using the ones that already exist. These bring two important challenges: 1 . Availability and technical characteristics of devices that are necessary to be able to do online activities created by the teacher and done by students; 2 . Training to develop skills and enough knowledge to use the devices as well as to be able to decide which piece of information is valuable and which one is not.

There is a complete universe of possibilities to explore new ways of interacting with students, between students, amongst teachers, between teachers and students. Even with the difficulty of accessibility to internet, in the following chart it is 
possible to observe different characteristics, educational uses, advantages, frequencies of consulting the source, examples of lessons, and names of different platforms that can be used as an idea for teachers that need to adapt to remote education in a more dynamic way. These options will be worthwhile if they promote the acquisition of meaningful learning through the exchange of knowledge previously acquired and the creation of new knowledge in a dynamic and interactive way. As presented in the following chart:

Chart 1: Characteristics of platforms and applications and possibilities to be used.

\begin{tabular}{|c|c|c|c|c|c|}
\hline Characteristics & Educational uses & Advantages/Benefits & $\begin{array}{l}\text { Frequency of } \\
\text { use }\end{array}$ & $\begin{array}{l}\text { Examples of } \\
\text { learning activities }\end{array}$ & Platforms/Material \\
\hline $\begin{array}{ll}\text { 1. } & \text { Multidinamic } \\
\text { 2. } & \text { Hipertextual } \\
\text { 3. } & \text { Pluridirectioal } \\
\text { 4. } & \text { Independent } \\
& \text { geographically } \\
\text { 5. } & \text { Independent in } \\
& \text { terms of time } \\
\text { 6. } & \text { Interactive } \\
\text { 7. } & \text { Oriented } \\
\text { 8. } & \text { Updated } \\
\text { 9. } & \text { Social }\end{array}$ & 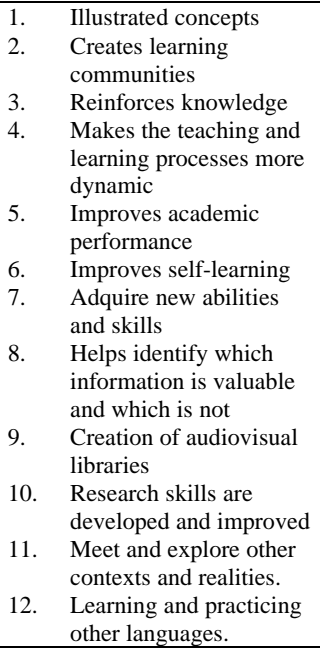 & $\begin{array}{ll}\text { 1. } & \text { Easy access and use } \\
\text { 2. } & \text { Free } \\
\text { 3. } & \text { Acces with no time or } \\
\text { 4ocation restrictions } \\
\text { 4. } & \text { Compatibility } \\
\text { 5. } & \begin{array}{l}\text { Motivation for } \\
\text { students }\end{array} \\
\text { 6. } & \text { Attractive interface } \\
\text { 7. } & \text { Dynamic }\end{array}$ & $\begin{array}{ll}\text { 1. } & \text { Everytime it is } \\
\text { required } \\
\text { 2. } \\
\text { It has a social } \\
\text { bonding but } \\
\text { also an } \\
\text { academic } \\
\text { perspective. }\end{array}$ & 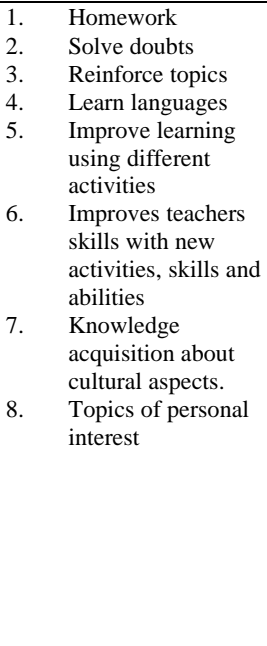 & $\begin{array}{ll}\text { 1. } & \text { Social Networks: } \\
& \text { Youtube, facebook, } \\
\text { instagram, TikTok } & \text { Platforms to teach: } \\
\text { 2. } & \text { Youtube, powtown, } \\
\text { jamboard, } & \text { padlet,,Genially, } \\
& \text { Voicethread } \\
\text { 3. } & \text { Interactive platforms: } \\
\text { zoom, google meets, } & \text { Microsoft teams, } \\
\text { whatsapp, telegram, } & \text { Edmodo, Balckboard, } \\
& \text { hangouts, Schoology } \\
\text { Google templates } \\
\text { Quizzy, wooclap, } \\
\text { TEDEx, }\end{array}$ \\
\hline
\end{tabular}

Source: Author's Ellaboration

It is important to transform human beings to learn about the changes that the sanitary emergency has brought due to the Covid-19 pandemic. This transformation is imperative and urgent. Human beings need to be aware that they are living in a globalized world and that they need to learn and dominate the global language: English. English is no longer a privilege; it is a must. Post pandemic human beings should be autonomous, they should raise their voice and take concrete actions for the environment, they need to fight for the preservation of life and ecosystems. They need to have the skill to learn in a socioaffective way, so they can see in other beings the best version of themselves (Pygmalion Effect). These post pandemic human beings should be pedagogical mediators through new ways of communicating, participating, and interacting in their learning processes. It is important to change the mental structure to configurate again processes and strategies to think for an academic life as fast, or even better faster than the speed of the pandemic. These rebuilt humans need to adapt to a new social life, a new Family life, a new working life, a new educational life, all of them mediated by technology. They should be capable of overcoming the "now" and move forward.

To move forward and transcend, it must be understood that English will allow people to interact and participate actively in their learning process and in their life. With this, he/she will be a subject that re-signify the world. For this it is necessary the mediating presence of teachers. Teachers are the ones who by sharing their knowledge in an empathetic way will stimulate the development of potential skills not only cognitive ones but also social, cultural, and emotional skills amongst students, which will be reflected in a transformed society.

In the same way, educational institutions need to adapt their curriculum according to the new needs of the pandemic and of the globalized world with a connectivity gap wider than ever. Autonomy must be strengthened, recreating spaces that are pedagogically creative and multimedial where students have the freedom and the responsibility to research and create scenarios to create, build and express themselves through new knowledge. Socio-affectiveness is one of the most important 
factors in this pandemic world because students need to learn that they are allowed to make mistakes, and therefore to relearn, so they can adapt constantly and continuously to the changes in this global pandemic mediated by technology, remote education and affective inclusion with gaps that are an unfortunate reality. $\mathrm{n}$ regards of learning English, a discursive competence is needed in the domain of general verbal exchanges that are common, diverse, global, and pandemic. Didactics for a second language should be thought not only in a discursive way but also in a textual, situational, and linguistic way. This contemporary and pandemic society is mediated by information technology, social distancing, and interactivity in the learning process and in social remote relations. A complete infrastructure should be created considering economy, technology and discourse in which English is promoted as part of being well prepared professionals with an optimum development of communicative competencies. In this way, the person and the student can communicate, recognize each other, interpret, and produce in a natural way signs, rules and senses from one language to another expressing an intention of communication according to the implicit elements of communication and with the demands of the pandemic globalized world. For this, professionals should improve their academic performance to be able to accomplish the following characteristics:

Figure 2: Characteristics of a professional in times of pandemic mediated by ICTs to learn a second language.

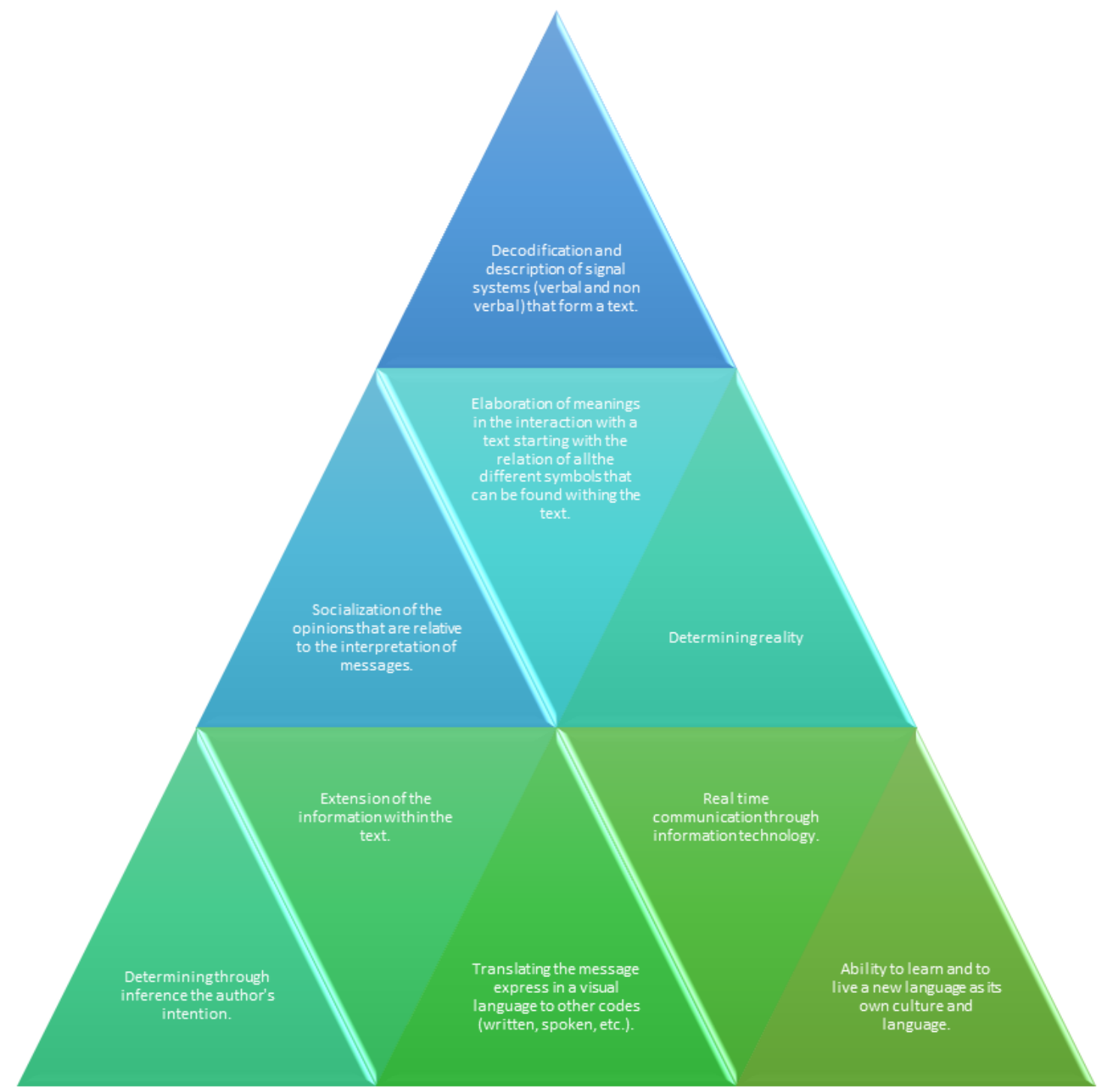

Source: Elaborated by the authors. 
It is valuable to note that having the skills for something does not imply that a person is competent with them. Competency does not depend on the skills but on the ability to use them for a specific purpose. To be competent it is necessary to get adapted in a practical and in a socio-affective way (Pygmalion effect).

These are then the challenges that teaching and learning English remotely face during the Covid-19 pandemic being inclusive with the Pygmalion effect.

\section{References}

Appenzeller, S., Menezes, F. H., Santos, G. G. D., Padilha, R. F., Graça, H. S., \& Bragança, J. F. (2020). Novos tempos, novos desafios: estratégias para equidade de acesso ao ensino remoto emergencial. Revista Brasileira de Educação Médica, 44.

Boser, U., Wilhelm, M., \& Hanna, R. (2014). The Power of the Pygmalion Effect: Teachers' Expectations Strongly Predict College Completion. Center for American Progress.

Cárdenas Vergaño, N. (2018). Perspectivas para un estudio sobre bilingüismo en universidades regionales colombianas. Revista historia de la educación latinoamericana, 20(31), 125-142.

Castillo Echevarría, R. (2014). El efecto Pigmalión. ¿Hasta qué punto determina nuestro futuro la visión que los demás tienen de nosotros?

Chávez-Zambano, M. X., Saltos-Vivas, M. A., \& Saltos-Dueñas, C. M. (2017). La importancia del aprendizaje y conocimiento del idioma inglés en la enseñanza superior. Dominio de las Ciencias, 3 (3 mon), 759-771.

Cocoma, L. A., \& Orjuela, M. A. (2017). Las TICS como recurso pedagógico para la enseñanza del inglés.

Cury, C. R. J. (2012). Direito à educação: direito à igualdade, direito à diferença. https://www.scielo.br/j/cp/a/x6g8nsWJ4MSk6K58885J3jd/?lang=pt

de Oliveira, H. F. M., da Silva, R. F., \& Pereira, V. A. (2021). Modos de aprender em tempos de pandemia: Deficiências e importância da inclusão digital para alunos da rede pública. Research, Society and Development, 10(7), e53410716610-e53410716610.

Gusso, H. L., Archer, A. B., Luiz, F. B., Sahão, F. T., Luca, G. G. D., Henklain, M. H. O., \& GonçPereira, V. M. (2020). Ensino superior em tempos de pandemia: diretrizes à gestão universitária. Educação \& Sociedade, 41.

Ibáñez, F. (2020). Educación en línea, Virtual, a Distancia y Remota de Emergencia, ¿cuáles son sus características y diferencias? https://observatorio.tec.mx/edu-news/diferencias-educacion-online-virtual-a-distancia-remota

INFOBAE (2021). Duque asegura que los 70 mil millones del contrato del mintic estan protegidos. Website Infoabe. https://www.infobae.com/america/colombia/2021/08/30/duque-asegura-que-los-70-mil-millones-del-contrato-del-mintic-estan-protegidos/

Ludke, M. \& Andre, M. E. D. A. (2013). Pesquisas em educação: uma abordagem qualitativa. Ed. EPU.

Miraz, M. D. C. G. (2014). Pigmalión en la escuela inclusiva. Cuadernos de pedagogía, (448), 76-80.

Pereira, V. A. (2020). Como está sendo o agora: aprendizagens na travessia da pandemia da Covid-19. Editora Amplla.

Pereira, V. A. (2020) ¿Qué será mañana?: Educación ambiental en américa latina y caribe, justicia ambiental y Covid-19. Garcia.

Pereira, V. A., \& Rosa, G. R. da. A atualidade da categoria Diálogo em Freire em tempos de "Escola sem partido". REMEA - Revista Eletrônica Do Mestrado Em Educação Ambiental, 91-111. https://doi.org/10.14295/remea.v0i0.6895. (2017).

Putra, P., Liriwati, F. Y., Tahrim, T., Syafrudin, S., \& Aslan, A. (2020). The students learning from home experiences during Covid-19 school closures policy in Indonesia. Jurnal Iqra': Kajian Ilmu Pendidikan, 5 (2), 30-42.

Restrepo, M. B. (2017). Análisis crítico desde la perspectiva curricular para la enseñanza del inglés en las universidades colombianas. Revista Lumen Gentium, 1(2), 47-60

Santos, J. V. (2020). A privatização da educação através das plataformas de ensino remoto: entrevista especial com Marcos Dantas. Instituto Humanitas Unisinos, 5.

Universidad del Quindío. (2006) Marco conceptual: definición, características, principios y valores. Lineamientos conceptuales. Lectura No 1 del diplomado en las Nuevas Tecnologías de la información y la investigación \& desarrollo vol 22, n 1 (2014) págs. 58-99 issn $2011-7574$ (on line) 98 Gustavo Rodríguez Albor, Viviana Gómez Lorduy, Marco Ariza Dau comunicación NTIC Aplicadas a la Educación Superior, Facultad de Educación. http://www.uniquindio.edu.co/uniquindio/ntic/lineamientos/documentos.htm

V Ramírez, A. (2009, September). La teoría del conocimiento en investigación científica: una visión actual. In Anales de la Facultad de Medicina. 70(3), 217224. UNMSM. Facultad de Medicina. 